\title{
Oral Glucose Tolerance Activity of Bawang Dayak (Eleutherine palmifolia L. Merr.) Bulbs Extract Based on the Use of different Extraction Method
}

\author{
Islamudin Ahmad ${ }^{1}$, Neneng Siti Silfi Ambarwati ${ }^{2}$, Niken Indriyanti ${ }^{1}$, Yurika Sastyarina ${ }^{1}$, Laode Rijai ${ }^{3}$, Abdul \\ Mun'im ${ }^{4}$
}

\begin{abstract}
Islamudin Ahmad', Neneng Siti Silfi Ambarwati ${ }^{2}$, Niken Indriyanti ${ }^{1}$, Yurika Sastyarina', Laode Rijai ${ }^{3}$, Abdul Mun'im ${ }^{4}$ 'Department of Pharmaceutical Sciences, Faculty of Pharmacy, Mulawarman University, Samarinda, East Kalimantan, 75119, INDONESIA. ${ }^{2}$ Faculty of Engineering, Universitas Negeri Jakarta, East Jakarta, 13220 INDONESIA.

${ }^{3}$ Pharmaceutical Research and Development Laboratory of FARMAKA TROPIS, Faculty of Pharmacy, Mulawarman University, Samarinda, East Kalimantan, 75119, INDONESIA. ${ }^{4}$ Department of Pharmaceutical Sciences, Faculty of Pharmacy, Universitas Indonesia, Depok, West Java, 16424, INDONESIA.

\section{Correspondence}

Islamudin Ahmad

Gedung Administrasi Fakultas Farmasi, Universitas Mulawarman, Jalan Penajam, Kampus UNMUL, Gunung Kelua, Samarinda, East Kalimantan, 75119, INDONESIA.

Phone no: +6281342205060

E-mail: islamudinahmad@farmasi.unmul. ac.id

History

- Submission Date: 16-05-2017;

- Review completed: 21-07-2017;

- Accepted Date: 27-08-2017

DOI : 10.5530/pj.2018.1.10

Article Available online

http://www.phcogj.com/v10/i1

\section{Copyright}

(C) 2018 Phcog.Net. This is an openaccess article distributed under the terms of the Creative Commons Attribution 4.0 International license.

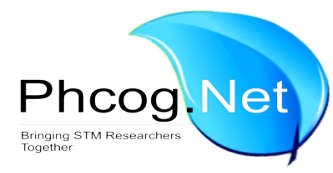

\begin{abstract}
Background: Bulbs of Bawang Dayak (Eleutherine palmifolia L. Merr; Synonym: Eleutherine americana L. Merr) from family Iridaceae is widely found and grown in Kalimantan island. The local tribe "Dayak" commonly consume this plant and become a traded commodity in traditional markets. This plant is trusted to treat various diseases. Objective: The present study aims to determine the effect of blood glucose reduction from bulbs of Bawang Dayak based on the use of different extraction methods using oral glucose tolerance test. Method: Dried sample was extracted with methanol using maceration, reflux, and Soxhlet method, respectively. The measurement of blood glucose reduction was performed using oral glucose tolerance test in vivo method and was analyzed using statistical comparison (Two-Way-ANOVA). Results: Based on the each extraction results was obtained yields of as $8.636 \%$ (reflux method), $11.87 \%$ (maceration method), and $14.023 \%$ (soxhlet method). While the results of blood glucose lowering effect on each extract were used, there were significant differences in statistical tests and organ index. Conclusion: This result is a preliminary stage and the information is invaluable for further research.

Key words: Bawang Dayak, Eleutherine palmifolia L. Merr, Bulbs of plant, Extraction method, Oral glucose tolerance test.
\end{abstract}

\section{INTRODUCTION}

Bawang Dayak (Eleutherine palmifolia L. Merr.; Synonym: Eleutherine americana L. Merr.) is a plant from family Iridaceae that widely found in Kalimantan island, Indonesia (particularly East Kalimantan) and widely grown in 600-2000 m above sea level. Traditionally used as a medicinal plant for treatment of sexual disorders, hypertension, stroke, diabetes mellitus, breast cancer, cyst, prostate, and used for increasing lactation production. ${ }^{1}$ Some study have reported the bulbs of the plant has activity as an antimicrobial, ${ }^{2}$ antioxidant, ${ }^{3}$ anti-dermatophyte, anti melanogenesis, ${ }^{4}$ sunscreen, ${ }^{5}$ aberrant $\mathrm{Wnt} / \beta$-catenin signaling inhibitor, ${ }^{6}$ a-glucosidase inhibitory, ${ }^{7}$ and antihyperglycemic. ${ }^{8}$ Bulbs of the plant contain anthraquinone, ${ }^{9,10}$ naphthoquinone group (elecanacine, eleutherine, elutherole, eleutherinone), ${ }^{4,11}$ and eleuthosides A, B, C. ${ }^{12}$ In Kalimantan island, the local tribe "Dayak" commonly consume this plant and become a traded commodity in traditional markets. The most commonly used parts are bulbs. Bulbs of the plant are one of the potential to be developed and further identified the active compounds. To be accepted in modern medicine, the plant as a medicinal raw material must meet the requirements, especially the content of the active substance and the level of safety. Because usually not all parts of the plant are used for treatment, even the chemical compounds they contain not all have the same properties. So need to do the extraction process by the desired target. A suitable method is required to separate the optimal target metabolites from the plant.

The most widely used conventional extraction methods are reflux, soxhlet, and maceration method. ${ }^{13,14}$ Selection of extraction methods can affect the content of secondary metabolites extracted from the plant. ${ }^{15}$ Some studies have reported that to obtain the maximum secondary target metabolite compound depends on the choice of the extraction method. ${ }^{16,17}$ For example, the effect of the extraction method on Cinnamomum burmanii (Nees and T, Nees) Blume extract, ${ }^{18}$ secondary metabolite extraction from Peperomia pellucida (L) Kunth, ${ }^{16}$ antioxidants extraction from Citrus limon Burm. ${ }^{19}$ As well as, the effect of extraction method from this bulbs against sunscreen activity. ${ }^{20}$

Oral glucose tolerance test (OGTT) is performed in the case of unclear hyperglycemia with glucose $(140-200 \mathrm{mg} / \mathrm{dl}$ or fasting glucose $(110-126 \mathrm{mg} / \mathrm{dl})$ or if there is unclear glucosuria. This test may be indicated in patients who are obese with a family history of diabetes Mellitus, in patients with vascular

Cite this article: Ahmad I, Ambarwati NSS, Indriyanti N, Sastyarina Y, Rijai L, Mun'im A. Oral Glucose Tolerance Activity of Bawang Dayak (Eleutherine palmifolia L. Merr.) Bulbs Extract Based on the use of different Extraction Method. Pharmacog J. 2018;10(1):49-54. 
disease, neurologic, or unclear infection. Also, this assay method is effectively used to determine of the blood glucose lowering activity on the experimental animal from a natural product. This approach hasbeen applied for diabetes control from some plantincluding Momordica carantia L., ${ }^{21}$ Coccinia cordifolia L., Chataranthus roseus L., ${ }^{22}$ Ipomoea aquatica, ${ }^{23}$ Phyllanthus acidus L., ${ }^{24}$ and so on. For screening or preliminary tests, the method is more efficient when compared to other in vivo test methods. Therefore, this method was selected and used as a preliminary assay based on the use of different extraction methods.

Some study have reported that bulbs of Bawang Dayak (E. palmifolia) have activity as antidiabetic ${ }^{8}$ and $\alpha$-glucosidase inhibitory activity (in vitro assay). ${ }^{7}$ Moreover, based on the best our knowledge, the pure of the active compound as antidiabetic and oral glucoside tolerance test of the bulb of plant based on the use of different extraction method had not been reported. The present study aims to determine the effect of glucose reduction from bulbs of plant based on the use of various extraction methods using oral glucose tolerance test, and expected from these results to be preliminary data for further research.

\section{MATERIALS AND METHODS}

\section{Plant and Chemical Materials}

The sample of Bawang Dayak (E. palmifolia) bulbs was collected from the traditional market in Samarinda, East Kalimantan, Indonesia. The voucher specimens were identified at Laboratory of Dendrology, Faculty of Forestry, Mulawarman University, Samarinda, Indonesia and was deposited at Laboratory of Pharmaceutical Research and Development of FARMAKA TROPIS, Faculty of Pharmacy, Mulawarman University, Samarinda, Indonesia. The fresh sample was washed with tap water to remove impurities on the sample surface and was dried using drying ovens at $50-60{ }^{\circ} \mathrm{C}$ temperature. The dried sample was powdered using a grinder. The powder obtained was stored at cool temperature until analysis. The chemical was used in this study, including Aqua demineralisation and methanol were purchased from SmartLab Indonesia; $10 \%$ glucose was acquired from PT. Widatra Bhakti, Indonesia; Metformin and Glibenclamide were purchased from PT. Kimia Farma, Indonesia.

\section{Animals}

Twenty-one Swiss albino mice (with a weight between 16-18 g) were used in the present study. The animals were obtained from Laboratory of Pharmacology, Faculty of Pharmacy, Mulawarman University, Samarinda, East Kalimantan, Indonesia. The animals were housed for three days under standard environment conditions. No mice died during this period. The study was conducted following approval by the Ethics Committee of the Faculty of Medicine, University of Indonesia, Depok, West Java, Indonesia. All procedures of ethical approval are performed by ICH-GCP standard procedure.

\section{Extraction Procedures}

The extraction process was conducted with three different extraction methods including maceration, reflux, and soxhlet method, respectively, based on literature ${ }^{20}$ with slight modification. Briefly, each $500 \mathrm{~g}$ of samples was extracted (the three different extraction methods) using methanol. Each of the obtained extract solutions was evaporated using a rotary evaporator. The obtained extract was stored at cool temperature until use.

\section{Oral Glucose Tolerance Test}

Oral glucose tolerance test was performed as per the procedure previously described by some literature ${ }^{21,24-26}$ with modification. Fasted mice were grouped into six groups of three mice each. Each group was given different treatment, including; Group I - III received extract (with dose $0.5 \mathrm{mg} / \mathrm{g}$ body weight) from three different extraction method (such as maceration, soxhlet, and reflux), respectively as test samples, Group IV received vehicle ( $10 \%$ Tween 20 in water) as a negative control, and Group V - VI received glibenclamide and metformin standard as a positive control. All substances were orally administered $(1 \mathrm{ml} / 20 \mathrm{~g}$ body weight). Blood glucose levels were measured at $0,30,60,90,120$, and $150 \mathrm{~min}$ load to access the effect of the extract on blood glucose levels of the glucose loaded animals. The blood glucose was measured using glucose test strips and glucometer (On-Call Plus Glucose Meter G114112 , USA).

\section{Statistical Analysis}

Experimental values were expressed as mean \pm SEM. Independent Sample t-test was conducted for statistical comparison (two-way ANOVA). The criterion for statistical significance was at a $p$-value less than 0.05 .

\section{RESULTS AND DISCUSSION}

\section{Extraction Process}

The extract was obtained based on the use of three different extraction method using methanol solvent. Methanol was selected because it has semipolar properties which are expected to attract polar and nonpolar compounds from a sample of Bawang Dayak (E. palmifolia). From each extraction methods was obtained the yields such as $8.636 \%$ (reflux method), $11.87 \%$ (maceration method), and 14.023\% (soxhlet method), respectively. More detail data can be seen in Table 1.

Based on the yields calculation in Table 1, the highest yield value was shown from the extraction using soxhlet method. The second highest yield value was the extraction using Soxhlet method, while the reflux method was the lowest yield value. It was due to the principle of each method. The soxhlet method uses a small amount of solvent without direct heating so that the solvent evaporation can be used continuously to attract the compound. In the reflux method, the sample and the solvent are mixed and require filtering after the extraction process is completed. Otherwise, direct heating may be able to cause the compound content to be damaged or lost resulting in fewer extracts. However, both methods only take a short time and a few solvents. While the maceration method conducted without heating, but it needs a long time and more solvent.

\section{Oral Glucose Tolerance Activity}

This study was carried out to determine the effect of blood glucose reduction on the three different extraction method of Bawang Dayak (E. palmifolia) bulbs against male mice (Mus musculus) using glucose tolerance test. The glucose tolerance test procedure aims to determine the ability of the samples test group in returning to the state of body homeostasis after blood glucose levels increased in normal male mice. The treatment begins by no feeding the mice for $18 \mathrm{~h}$ to avoid elevated blood glucose levels. The measurement results of blood glucose level in the early $\min (t=0 \mathrm{~min})$ of mice after giving $75 \mathrm{~g}$ glucose in each treatment group obtained a value between $87-110 \mathrm{mg} / \mathrm{dl}$ then measured at 30 , $60,90,120$ and $150 \mathrm{~min}$. The measurement results of mean blood glucose levels in mice can be seen in Table 2 and the profile of mean blood glucose levels in mice showed in Figure 1.

In each treatment group showed changes in glucose levels ranging from 30 to 150 min which led to high deviation standard data. From these results indicated that an increase in serum glucose at 30-60 min and decreased in 90-150 min. Based on the result of treatment with extract on various extraction methods (group I-III) showed a significant difference in decreasing blood glucose level compared to con- 
Table 1: The Yields of E. palmifolia (L) Merr extract based on the use of different extraction method.

\begin{tabular}{ccc}
\hline Extraction methods & Yield $(\mathbf{g})$ & Percentace of Yields $(\% \mathrm{w} / \mathrm{w})$ \\
\hline Reflux & 70.113 & 14.023 \\
Soxhlet & 43.13 & 8.626 \\
Maceration & 59.352 & 11.870 \\
\hline
\end{tabular}

\begin{tabular}{|c|c|c|c|c|c|c|}
\hline \multirow{2}{*}{$\begin{array}{l}\text { Treatment } \\
\text { Group }\end{array}$} & \multicolumn{6}{|c|}{ Mean reduction glucose tolerance levels after treatment $(\mathrm{mg} / \mathrm{dl})$} \\
\hline & Minute-0 & Minute-30 & Minute-60 & Minute-90 & Minute-120 & Minute-150 \\
\hline I & $100,67 \pm 19,55$ & $106,33 \pm 21,12$ & $105,33 \pm 21$ & $95,67 \pm 20,88$ & $90 \pm 17,90$ & $93,33 \pm 24,68$ \\
\hline II & $87 \pm 11,53$ & $75,67 \pm 18,03$ & $76,33 \pm 19,55$ & $70,67 \pm 20,03$ & $70,67 \pm 21$ & $71,33 \pm 23,50$ \\
\hline III & $108 \pm 3,46$ & $98 \pm 4$ & $99 \pm 1,73$ & $96 \pm 2,88$ & $95 \pm 8,66$ & $95 \pm 8,66$ \\
\hline IV & $93,67 \pm 19,26$ & $88 \pm 21,28$ & $92,33 \pm 19,34$ & $87,33 \pm 19,34$ & $83,33 \pm 20,25$ & $84,33 \pm 115,01$ \\
\hline $\mathrm{V}$ & $91 \pm 10,44$ & $59 \pm 8,66$ & $51 \pm 3,60$ & $48,5 \pm 8,66$ & $54 \pm 6,08$ & $56 \pm 6,08$ \\
\hline VI & $110 \pm 12,28$ & $96 \pm 24,63$ & $101 \pm 17,08$ & $85,33 \pm 8,14$ & $81,55 \pm 9,50$ & $81,67 \pm 13,50$ \\
\hline
\end{tabular}

Where: Group I is extract with maceration method; Group II is extract with soxhlet method; Group III is extract with reflux method; Group IV is negative control; Group V is glibenclamide as positive kontrol 1; and Group VI is metformin as positive control 2.

Table 3: Percentage decrease of mean glucose tolerance levels of Bawang Dayak (E. palmifolia) bulb extract using oral glucose tolerance test

\begin{tabular}{ccccccc}
\hline \multirow{2}{*}{ Treatment Group } & \multicolumn{5}{c}{ Percentage decrease of mean glucose tolerance levels (\%) } \\
\cline { 2 - 7 } & 0 & 30 & 60 & 90 & 120 & 150 \\
\hline I & $100 \pm 0$ & $89,42 \pm 2,75$ & $81,33 \pm 3,02$ & $74,60 \pm 7,98$ & $79,08 \pm 43$ & $76,68 \pm 12,28$ \\
II & $100 \pm 0$ & $86,16 \pm 10,01$ & $86,77 \pm 11,67$ & $80,14 \pm 13,12$ & $80,10 \pm 14,40$ & $80,61 \pm 17,19$ \\
III & $100 \pm 0$ & $90,73 \pm 1,84$ & $91,74 \pm 4,05$ & $62,2 \pm 45,83$ & $88,14 \pm 5,57$ & $87,75 \pm 9,39$ \\
IV & $100 \pm 0$ & $93,47 \pm 4,14$ & $98,54 \pm 3,96$ & $92,13 \pm 6,06$ & $89,09 \pm 10,68$ & $90,55 \pm 5,42$ \\
V & $100 \pm 0$ & $64,43 \pm 14,27$ & $55,12 \pm 1,51$ & $55,17 \pm 9,55$ & $58,23 \pm 1,77$ & $60,4 \pm 1,73$ \\
VI & $100 \pm 0$ & $86,40 \pm 13,18$ & $90,55 \pm 6,46$ & $76,2 \pm 3,41$ & $74,25 \pm 3,8$ & $74,18 \pm 8,47$ \\
\hline
\end{tabular}

Where: Group I is extract with maceration method; Group II is extract with soxhlet method; Group III is extract with reflux method; Grou IV is negative control; Group V is glibenclamide as positive kontrol 1; and Group VI is metformin as positive control 2

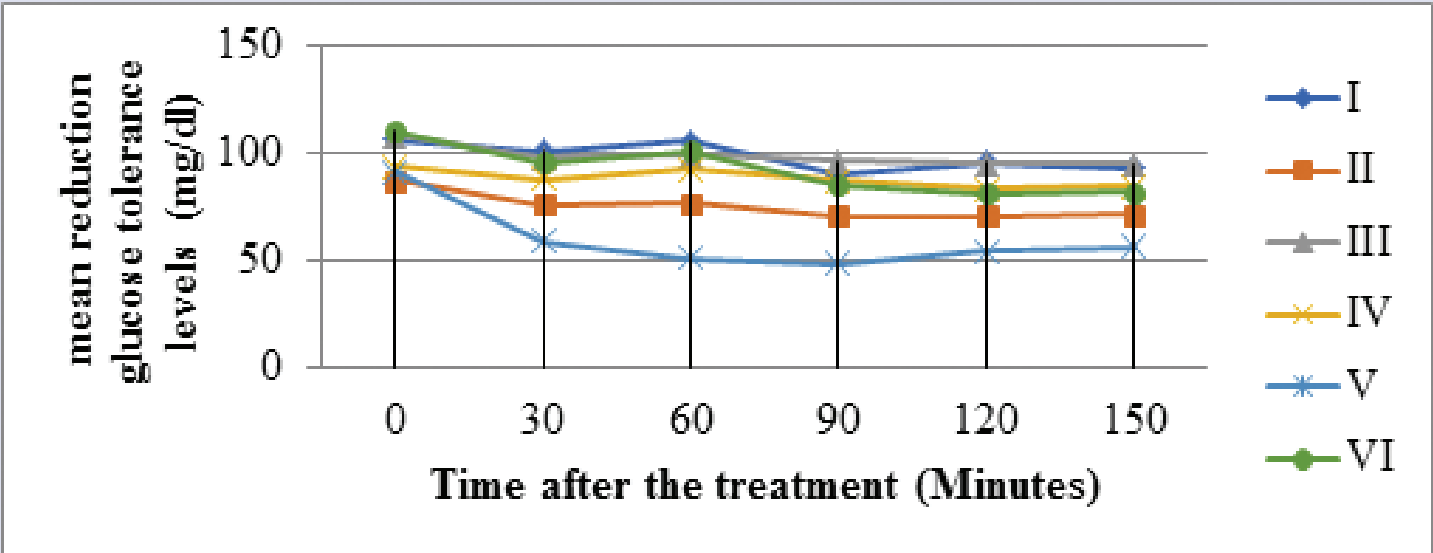

Figure 1: Graphs of mean reduction glucose tolerance levels of Bawang Dayak (E. palmifolia) bulb extract. Where: Group I is extraction with maceration method, Group II is extraction with Soxhlet method, Group III is extraction with reflux method, Grou IV is negative control, Group V is glibenclamide as positive control 1, and Group VI is metformin as positive control 2. 


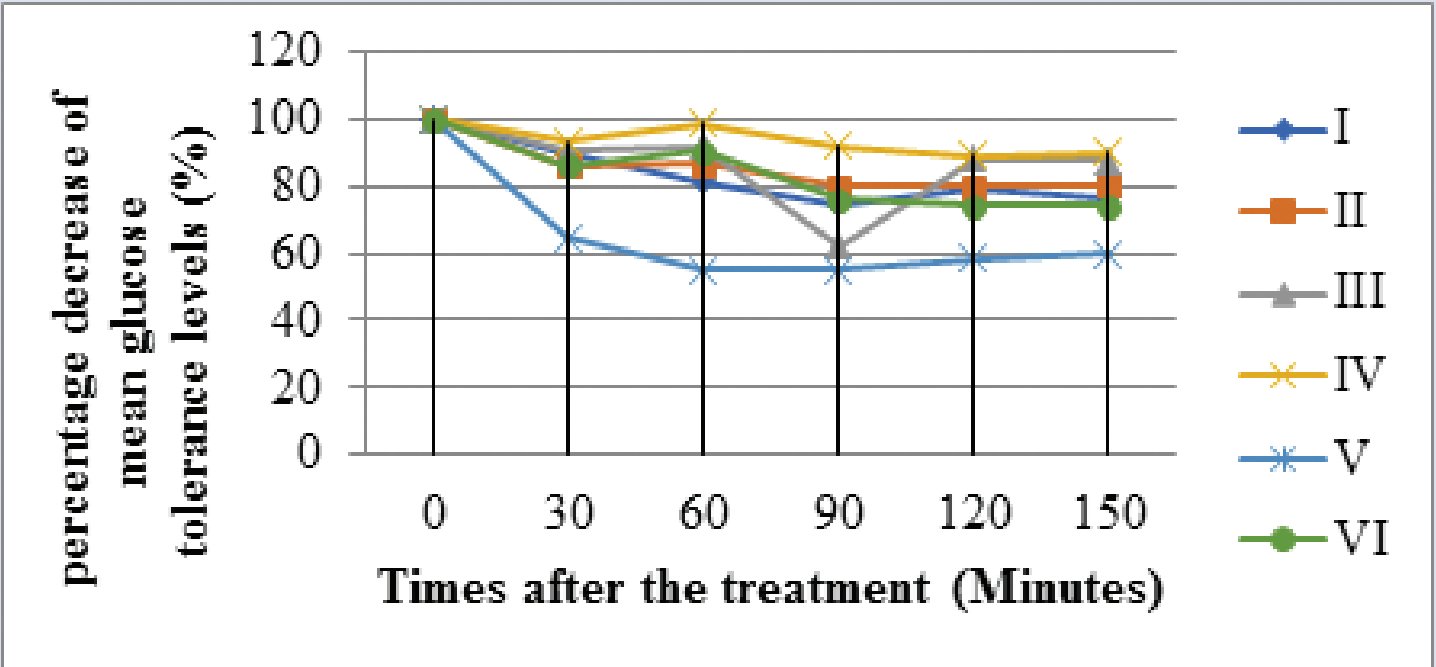

Figure 2: Graphs of percentage decrease of mean glucose tolerance levels of Bawang Dayak (E. palmifolia) bulb extract.

Where: Group I is extraction with maceration method, Group II is extraction with Soxhlet method, Group III is extraction with reflux method, Grou IV is negative control, Group V is glibenclamide as positive control 1, and Group VI is metformin as positive control 2 .

trol group $(\mathrm{p}<0,05)$ and average decreased at $90 \mathrm{~min}$. The reduction of blood glucose level of each treatment group at a certain time was more clearly visible in the form of mean percent value of blood glucose level change compared to the baseline level (min-0) which can be seen in Table 3, and graphs percent change in blood glucose levels in each group can be seen in Figure 2. Based on the mean percentage calculation of changes in blood glucose level compared to baseline (min-0), the largest percentage in group III (reflux extraction method) and the group I (maceration extraction method) were $62.2 \%$ and $74.6 \%$. The result of the two-way ANOVA statistical analysis on the mean percentage of change was found that between the test groups (I-VI) there was a significant difference with the control group $(\mathrm{p}<0.05)$. While probability based on time in each group there was a significant difference $(\mathrm{p}<0,05)$ and seen from interaction test between group and time there was an interaction between variables.

Based on observed changes in the organ index, there was a difference in magnification of the bladder compared to the treatment of glucoseinduced controls and untreated. In the extract (soxhlet and maceration method) showed the presence of bladder enlargement, whereas in giving extract with reflux method does not occur enlargement. Then compared with glibenclamide and metformin, it can be seen that the treatment with glibenclamide occurs enlargement and the treatment with metformin do not occur. It was probably due to the different working mechanisms of both medicines when compared with each treatment of the three types of extracts. Based on index organs, we conclude that the treatment of extract with soxhlet and maceration method has a similar action mechanism with glibenclamide, whereas extract by reflux method has a similar mechanism of action with metformin.

\section{CONCLUSION}

Based on the results of this study, the effect of activity as a decrease in blood glucose from each method of extraction was different on the statistical tests and organ index. The difference was the possibility of having a different mechanism of action. This study was a preliminary stage, and the information is invaluable for further research which includes in vivo antidiabetic assay, isolation, and characterization of the active compound.

\section{ACKNOWLEDGEMENT}

We thank Head Pharmaceutical Research and Development Laboratory of FARMAKA TROPIS and Dean Faculty of Pharmacy, Mulawarman University of the facility and financial support.

\section{CONFLICT OF INTEREST}

All author declared that has no conflict of interest.

\section{ABBREVIATION USED}

OGTT; oral glucose tolerance test, ICH-GCP; international conference on harmonisation - good clinical practice, SEM; structural equation modeling, ANOVA; analysis of variance, E. palmifolia; Eleutherine palmifolia L. Merr.

\section{REFERENCES}

1. Galingging RY. Dayak onion (Eleutherine palmifolia) as multifunctional medicinal plants. Warta Penelitian dan Pengembangan. 2009;153:1-4. (In Bahasa)

2. Subramaniam K, Suriyamoorthy S, Wahab F, Sharon FB, Rex GR. Antagonistic activity of Eleutherine palmifolia Linn. Asian Pacific JTrop Dis. 2012;2(SUPPL 1): S491-3. doi: 10.1016/S2222-1808(12)60208-4.

3. Kuntorini EM, Dewi M, Misrina. Anatomical structure and antioxidant activity of red bulb plant (Eleutherine americana) on different plant age. Biodiversitas. 2016;17(1):229-33. doi: 10.13057/biodiv/d170133.

4. Kusuma IW, Arung ET, Rosamah E, Purwatiningsih S, Kuspradini H, Syafrizal, et al. Antidermatophyte and antimelanogenesis compound from Eleutherine americana grown in Indonesia. J Nat Med. 2010;64(2):223-6. doi: 10.1007/ s11418-010-0396-7.

5. Ahmad I, Agus ASR. Uji stabilitas formula krim tabir surya ekstrak umbi Bawang Dayak (Eleutherine americana L. Merr.). J Trop Pharm Chem. 2013;2(3):159-65.

6. Li X, Ohtsuki T, Koyano T, Kowithayakorn T, Ishibashi M. New Wnt/ $\beta$-catenin signaling inhibitors isolated from Eleutherine palmifolia. Chem Asian J. 
2009;4(4):540-7. doi: 10.1002/asia.200800354.

7. Ieyama T, Gunawan-Puteri MDPT, Kawabata J. $\alpha$-Glucosidase inhibitors from the bulb of Eleutherine americana . Food Chem. 2011;128(2):308-11. doi: 10.1016/j. foodchem.2011.03.021

8. Febrinda AE, Yuliana ND, Ridwan E, Wresdiyati T, Astawan M. Hyperglycemic control and diabetes complication preventive activities of Bawang Dayak (Eleutherine palmifolia L. Merr.) bulbs extracts in alloxan-diabetic rats. Int Food Res J. 2014;21(4):1405-11.

9. Paramapojn S, Ganzera M, Gritsanapan W, Stuppner H. Analysis of naphthoquinone derivatives in the Asian medicinal plant Eleutherine americana by RP-HPLC and LC-MS. J Pharm Biomed Anal. 2008;47(4,5):990-3. doi: 10.1016/j. jpba.2008.04.005

10. Xu J, Qiu F, Duan W, Qu G, Wang N, Yao X. New bioactive constituents from Eleutherine americana. Front Chem China. 2006;1(3):320-3. doi:10.1007/ s11458-006-0032-7.

11. Hara H, Maruyama N, Yamashita S, Hayashi KHL, Bastow, KF, Chairul, et al Elecanacin, a novel new naphthoquinone from the bulb of Eleutherine americana. Chem Pharm Bull. 1997:45(10):1714-6.

12. Shibuya H, FukushimaT, Ohashi K, Nakamura A, Riswan S, Kitagawa I. Indonesian Medicinal Plants. XX. Chemical Structures of Eleuthosides A, B, and C, Three New Aromatic Glucosides from the Bulbs of Eleutherine palmifolia (Iridaceae). Chem Pharm Bull. 1997;45(7):1130-4. doi: 10.1248/cpb.45.1130.

13. Calzada F, Solares-Pascasio JI, Ordoñez-Razo RM. Antihyperglycemic activity of the leaves from Annona cherimola miller and rutin on alloxan-induced diabetic rats. Pharmacognosy Res. 2017;9(1):1-6. doi: 10.4103/0974-8490.199781.

14. Hanani E. Analisis Fitokimia. Jakarta: Penerbit Buku Keokteran, EGC. 2015

15. Cseke LL, Kirakosyan A, Kaufman PB, Walber SL, Duke JA, Brielmann HL. Natural Products from Plants. Second Ed. Boca Raton, London, New York: Taylor and Francis. 2006

16. Ahmad I, Yanuar A, Mulia K, Mun'im A. Application of ionic liquid based microwave-assisted extraction of the secondary metabolite from Peperomia pellucida (L) Kunth. Pharmacogn J. 2017;9(2):227-34. doi: 10.5530/pj.2017.2.38.

17. Ogaji IJ, Nan A, Hoag SW. A Novel extraction method and some physicochemical properties of extractives of Irvingia gabonensis seeds. J Young Pharm.
2008;4(2):66-71. doi: 10.1002/ejlt.200700172.

18. Wardatun S, Rustiani E, Alfiani N, Rissani D. Bioinsecticide effect of Pinus merkusii tree bark extract on Aedes aegypti larvae. J Young Pharm. 2017;9(1):118-21. doi: 10.5530/jyp.2017.

19. Akhila S, Bindu A, Bindu K, Aleykutty N. Comparative evaluation of extracts of Citrus limon Burm Peel for Antioxidant Activity. J Young Pharm. 2009:1(2):136 doi: 10.4103/0975-1483.55746.

20. Ahmad I, Arifuddin M, Rijai L. The effect of extraction methods of Bawang Dayak (Eleutherine palmifolia L. MERR) against TLC profiles and sunscreen activities. Int J PharmTech Res. 2016;9(9):428-36.

21. Leatherdale $\mathrm{Ba}$, Panesar RK, Singh G, Atkins TW, Bailey CJ, Bignell AHC Improvement in glucose tolerance due to Momordica charantia (karela). Br Med $\mathrm{J}$ (Clin Res Ed). 1981;282(6279):1823-4. doi: 10.1136/bmj.282.6279.1823.

22. Islam MA Akhtar MA, Khan MRI, Hossain MS, Alam AHMK, Wahed MII, et al. Oral glucose tolerance test (OGTT) in normal control and glucose induced hyperglycemic rats with Coccinia cordifolia L. and Catharanthus roseus L. Pakistan J Pharm Sci. 2017;22(4):402-4.

23. Hosen MS, Rahim MA, Rahmatullah M. Synergistic action of glibenclamide and methanol extract of Ipomoea aquatica aerial parts in oral glucose tolerance tests. World J Pharm Pharm Sci. 2016;5(11):1697-701.

24. Chaimum-aom N, Chomko S, Talubmook C. Toxicology and oral glucose tolerance test (OGTT) of Thai medicinal plant used for Diabetes controls, Phyllanthus acidus L. (Euphorbiaceae). Pharmacogn J. 2016;9(1):58-61. doi: 10.5530/pj.2017.1.11

25. Saha M, Rohani S, Rayhana N, Toma IJ, Rana S, Rahmatullah M. An herba formulation containing Zingiber officinale rhizomes and Allium sativum cloves can increase oral glucose tolerance in mice. Biol Eng Med Biol Eng Med. 2017;2(1):1-3. doi: 10.15761/BEM.1000110

26. Zidani S, Benakmoum A, Ammouche A, Benali Y, Bouhadef A, Abbeddou S Effect of dry tomato peel supplementation on glucose tolerance, insulin resistance, and hepatic markers in mice fed high-saturated-fat/high-cholestero diets. J Nutr Biochem. 2017;40:164-71. doi: 10.1016/j.jnutbio.2016.11.001.

\section{GRAPHICAL ABSTRACT}

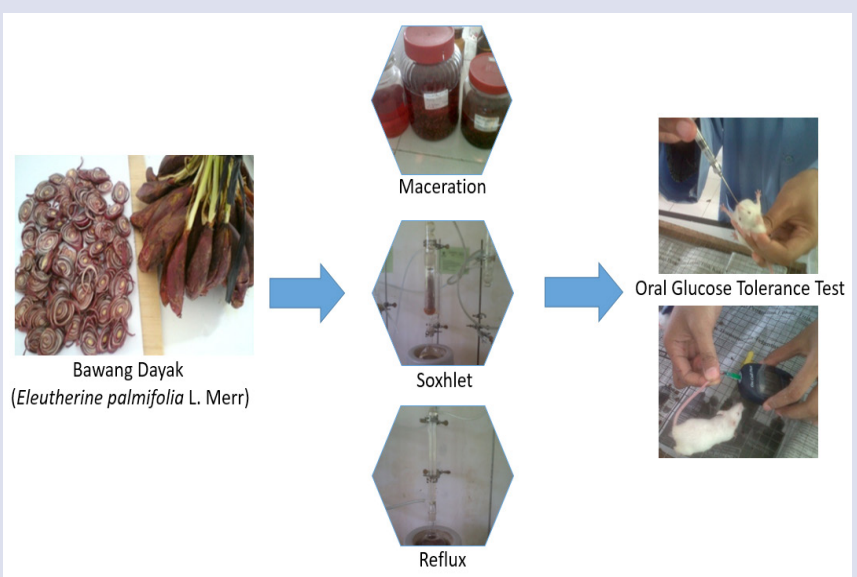

\section{SUMMARY}

- The bulb of Bawang Dayak (Eleutherine palmifolia L. Merr.) is consumed by the local tribe "Dayak" and trusted to treat various diseases.

- Each extraction results were obtained yields of as $8.636 \%$ (Reflux method), $11.87 \%$ (Maceration method), and $14.023 \%$ (Soxhlet method).

- The blood glucose lowering effect on each extract were used, there were significant differences in statistical tests and organ index.

- This result is a preliminary stage and the information is invaluable for further research.

\section{ABOUT AUTHORS}

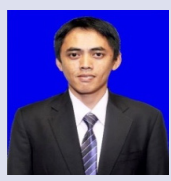

Islamudin Ahmad, a Doctoral Candidate at Department of Pharmaceutical Sciences, Faculty of Pharmacy, Universitas Indonesia (UI), Depok, West Java, Indonesia. He is a lecturer at Faculty of Pharmacy, Mulawarman University, Samarinda, East Kalimantan, Indonesia. The doctoral research focused on the study of extraction engineering, screening activity and angiotensin converting enzyme (ACE) inhibitory active compound from the natural product for drugs discovery as antihypertension.

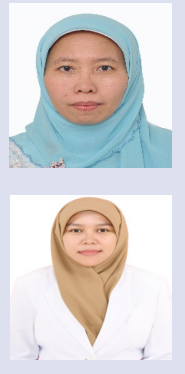

Neneng Siti Silfi Ambarwati, a Doctoral Candidate at Department of Pharmaceutical Sciences, Faculty of Pharmacy, Universitas Indonesia, Depok, West Java, Indonesia. She is a lecturer at Department of Health and Beauty, Faculty of Engineering, Jakarta State University, Jakarta, Indonesia. The doctoral research focused on the isolation, identification, semi-synthetic of the active compound as antibacterial.

Niken Indriyanti, a Doctoral Candidate at Faculty of Pharmacy, Airlangga University, Surabaya, East Java, Indonesia, She is a lecturer at Faculty of Pharmacy, Mulawarman University, Samarinda, East Kalimantan, Indonesia. The doctoral research focused on the pharmacological properties of natural product. 


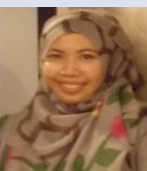

Yurika Sastyarina, a Doctoral Candidate at Department of Chemistry, Faculty of Mathematics and Natural Sciences, Padjadjaran University, Bandung, West Java, Indonesia. She is a lecturer at Faculty of Pharmacy, Mulawarman University, Samarinda, East Kalimantan, Indonesia. The doctoral reseach focused on the biochemistry of pharmacy and drug design.

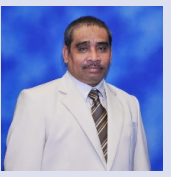

Dr. Laode Rijai, Associate Professor and Dean at Faculty of Pharmacy, Mulawarman University, Samarinda, East Kalimantan, Indonesia. He has experience in the area of Natural Product and Organic Chemistry.

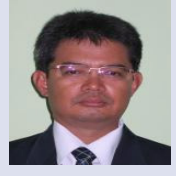

Dr. Abdul Mun'im, Associate Professor at Departement of Pharmaceutical Sciences, Faculty of Pharmacy, Universitas Indonesia (UI) Depok, West Java, Indonesia. He has experience in the area of Pharmacognosy and Phytochemistry, working in drugs discovery of herbal plants, extraction engineering, Metabolite profiling, Structure Elucidation, and Degenerative Diseases (such as diabetes mellitus, antihypertension, and cholesterol).

Cite this article: Ahmad I, Ambarwati NSS, Indriyanti N, Sastyarina Y, Rijai L, Mun'im A. Oral Glucose Tolerance Activity of Bawang Dayak (Eleutherine palmifolia L. Merr.) Bulbs Extract Based on the use of different Extraction Method. Pharmacog J. 2018;10(1):4954. 